\title{
Electroencephalographic Frequency Patterns of Rats Treated with Aminopterin in Early Infancy*
}

\author{
Tsuneo Arakawa, Takashi Mizuno, Kazuo Sakai, Kazunobu Chida, \\ Ayuko Watanabe and Kazuo Ohara \\ Department of Pediatrics (Prof. Ts. Arakawa), \\ Faculty of Medicine, Tohoku University, Sendai \\ David Baird Coursin \\ Director of Research Institute, St. Joseph Hospital, \\ Lancaster, Pennsylvania
}

\begin{abstract}
Aminopterin was given to dams on the 4th, 10th and 18th days after delivery and to offsprings on the 18th day of life, and the frequency analysis of electroencephalograms of the offsprings was done at the age of $3,4,5,6$ and 7 weeks.

A definite delay of maturation of the brain function was observed in rats treated with aminopterin when EEG was examined at the age of 5,6 and 7 weeks.

In this study an analyzer of basic waves of electroencephalograms was specially prepared so as to be able to observe slight changes in areas with slow waves.
\end{abstract}

The aim of the present study is to examine the effect of folic acid deficiency in early infancy upon the maturation of the brain function of rats.

Folic acid deficiency was induced by administration of aminopterin to dams and offsprings soon after birth. The maturation of the brain function was evaluated by frequency analysis of electroencephalograms by using an analyzer which was specially prepared so as to demonstrate variations in slow basic waves of EEG.

\section{Methods and Materials}

Albino Wistar rats were used throughout this study and placed on a standard diet purehased from Oriental Co. Tokyo, Japan.

The diet and water were given ad libitum. The size of litters was made to be 8 in number.

Aminopterin injection: Aminopterin was dissolved in $0.85 \% \mathrm{NaCl}$ solution and neutralized with NaOH. The aminopterin solution was injected intraperitoneally to dams and offsprings in the following way: In the case of dams, $0.038 \mathrm{mg}$ per $\mathrm{kg}$ of bodyweight each on the 4 th and 10th days after delivery and $0.076 \mathrm{mg}$ per $\mathrm{kg}$ of bodyweight on the 18th day after delivery; in the case of offsprings, $0.038 \mathrm{mg}$ per $\mathrm{kg}$ of bodyweight was given only on the 18th day of life.

Received for publication, January 23, 1969.

* Supported in part by a grant of National Institute of Child Health and Human Development. 
Estimation of integrated voltage of frequency bands: A 12 channel electroencepharograph (Toshiba ST-2477-A) was used.

Needle electrodes were inserted into the surface of the cortex of the visual area and fixed to the scalp with use of dental sement.

By means of an analyzer specially prepared, the basic waves of EEG were divided into 10 bands according to the frequency in the following way: I band, 2-2.4 c/s; II band, $2.4-2.88 \mathrm{c} / \mathrm{s}$; III band, $2.88-3.46 \mathrm{c} / \mathrm{s}$; IV band, $3.46-4.15 \mathrm{c} / \mathrm{s} ; \mathrm{V}$ band, $4.15-4.98 \mathrm{c} / \mathrm{s} ; \mathrm{VI}$ band, $4.98-5.97 \mathrm{c} / \mathrm{s}$; VII band, $5.97-7.17 \mathrm{c} / \mathrm{s}$; VIII band, 7.17-8.60 o/s; IX band, 8.60-10.3 $\mathrm{c} / \mathrm{s}$; and $\mathrm{X}$ band, $10.3-12.4 \mathrm{c} / \mathrm{s}$.

The integrated voltages at each of the frequency bands (bands $I-X$ ) were estimated on records obtained from six epochs of 10 sec and were averaged. They were expressed as energy $\%(\mathbb{E} \%)$ calculated according to the following formula:

$\mathrm{E} \%$ for the band $\mathrm{I}=\left[\mathrm{I}^{2} /\left(\mathrm{I}^{2}+\mathrm{II}^{2}+\ldots+\mathrm{X}^{2}\right)\right] \times 100$

Analysis of EEG using the above method was carried out on 3 rats each of control and aminopterin-treated groups at $3,4,5,6$ and 7 weeks of life.

\section{Results and Discussion}

Results obtained were given in Tables 1-5. Fig. 1 was drawn from average values of energy $\%$ of each band in control rats at the age of 3,5 and 7 weeks, showing that there was a tendency to a decrease in energy \% at I-II bands associated with an increase in energy \% at VI-VIII bands with the advance in age.

TABLE 1. Results of frequency analysis of basic waves of EEG in rats with or without aminopterin-treatment. EEG was examined at the age of 3 weeks

\begin{tabular}{|c|c|c|c|c|c|c|c|c|c|c|c|}
\hline \multirow{2}{*}{ Group } & \multirow{2}{*}{$\begin{array}{l}\text { No. } \\
\text { of } \\
\text { rats }\end{array}$} & \multicolumn{10}{|c|}{ Energy \% } \\
\hline & & I & II & III & IV & $\nabla$ & VI & VII & VIII & IX & $X$ \\
\hline \multirow{4}{*}{ Control } & I & 17.4 & 13.2 & 14.5 & 11.9 & 8.4 & 8.4 & 8.4 & 7.4 & 5.6 & 4.7 \\
\hline & 3 & 15.0 & 16.9 & 13.2 & 11.5 & 9.9 & 9.9 & 9.9 & 5.8 & 5.8 & 2.1 \\
\hline & 5 & 15.8 & 11.2 & 12.7 & 14.2 & 11.2 & 9.9 & 9.9 & 6.3 & 5.3 & 3.5 \\
\hline & Average & 16.0 & 13.7 & 13.4 & 12.5 & 9.8 & 9.4 & 9.4 & 6.5 & 5.5 & 3.4 \\
\hline \multirow{4}{*}{$\begin{array}{l}\text { Treated } \\
\text { with } \\
\text { aminopterin }\end{array}$} & 2 & 17.9 & 16.5 & 16.5 & 10.3 & 9.3 & 9.3 & 6.4 & 5.6 & 4.8 & 3.5 \\
\hline & 4 & 14.3 & 13.2 & 9.2 & 12.1 & 10.1 & 10.1 & 11.1 & 7.4 & 7.4 & 5.1 \\
\hline & 6 & 18.1 & 12.4 & 11.4 & 9.5 & 10.1 & 10.4 & 10.4 & 7.0 & 6.2 & 4.2 \\
\hline & Average & 16.7 & 14.0 & 12.3 & 10.6 & 9.9 & 9.9 & 9.3 & 6.6 & 6.1 & 4.2 \\
\hline
\end{tabular}

TABLE 2. Results of frequency analysis of basic waves of EEG in rats with or without aminopterin-treatment. EEG was examined at the age of 4 weeks

\begin{tabular}{|c|c|c|c|c|c|c|c|c|c|c|c|}
\hline \multirow{2}{*}{ Group } & \multirow{2}{*}{$\begin{array}{l}\text { No. } \\
\text { of } \\
\text { rats }\end{array}$} & \multicolumn{10}{|c|}{ Energy \% } \\
\hline & & $\mathrm{I}$ & II & III & IV & $\mathrm{V}$ & VI & VII & VIII & XI & $X$ \\
\hline \multirow{4}{*}{ Control } & 7 & 14.3 & 11.8 & 14.3 & 13.0 & 11.8 & 9.6 & 8.5 & 6.6 & 5.8 & 4.3 \\
\hline & 8 & 12.7 & 10.2 & 12.1 & 13.5 & 14.2 & 10.2 & 9.0 & 6.8 & 6.3 & 4.9 \\
\hline & 9 & 9.8 & 8.9 & 13.0 & 15.3 & 10.8 & 8.9 & 9.8 & 10.8 & 7.9 & 4.8 \\
\hline & Average & 12.2 & 10.3 & 13.1 & 13.9 & 12.2 & 9.5 & 9.1 & 8.0 & 6.6 & 4.6 \\
\hline \multirow{4}{*}{$\begin{array}{l}\text { Treated } \\
\text { with } \\
\text { aminopterin }\end{array}$} & 10 & 17.4 & 17.4 & 15.1 & $13 \cdot 1$ & 11.8 & 8.3 & 6.3 & 4.5 & 3.4 & 2.8 \\
\hline & 11 & 8.8 & 8.8 & 10.3 & 13.8 & 15.7 & 13.8 & 12.9 & 8.1 & 4.4 & 3.4 \\
\hline & 12 & 12.5 & 10.9 & 11.7 & 11.7 & 10.9 & 10.1 & 10.1 & 8.0 & 8.0 & 6.1 \\
\hline & Average & 12.9 & 12.3 & 12.3 & 12.8 & 12.8 & 10.7 & 9.7 & 6.8 & 5.2 & 4.1 \\
\hline
\end{tabular}


TABLE 3. Results of frequency analysis of basic waves of EEG in rats with or without aminopterin-treatment. EEG was examined at the age of 5 weeks

\begin{tabular}{|c|c|c|c|c|c|c|c|c|c|c|c|}
\hline \multirow{2}{*}{ Group } & \multirow{2}{*}{$\begin{array}{l}\text { No. } \\
\text { of } \\
\text { rats }\end{array}$} & \multicolumn{10}{|c|}{ Energy \% } \\
\hline & & I & II & III & IV & V & VI & VII & VIII & $1 X$ & $\mathrm{X}$ \\
\hline \multirow{4}{*}{ Control } & 13 & 6.4 & 6.4 & 6.4 & 11.9 & 15.3 & 13.5 & 11.9 & 8.9 & 10.4 & 8.9 \\
\hline & 14 & 7.1 & 6.2 & 9.1 & 11.3 & 18.1 & 15.2 & 12.6 & 8.0 & 7.1 & 5.3 \\
\hline & 15 & 11.5 & 9.5 & 9.5 & 11.5 & 13.7 & 13.7 & 11.5 & 4.7 & 4.7 & 9.5 \\
\hline & Average & 8.3 & 7.3 & 8.3 & 11.5 & 15.7 & 14.1 & 12.0 & 7.2 & 7.5 & 7.9 \\
\hline \multirow{4}{*}{$\begin{array}{l}\text { Treated } \\
\text { with } \\
\text { aminopterin }\end{array}$} & 16 & 10.1 & 12.5 & 18.2 & 20.4 & 12.5 & 9.3 & 7.2 & 4.3 & 2.9 & 2.5 \\
\hline & 17 & $9-6$ & 8.5 & 13.3 & 14.7 & 16.1 & 12.0 & 9.6 & 6.5 & 5.6 & 4.0 \\
\hline & 18 & 9.7 & 8.7 & 11.7 & 11.7 & 13.9 & 12.8 & 10.6 & 7.8 & 7.0 & 6.2 \\
\hline & & 9.8 & 9.9 & 14.4 & 15.6 & 14.1 & 11.3 & 9.1 & 6.2 & 5.1 & 4.0 \\
\hline
\end{tabular}

TABLE 4. Results of frequency analysis of basic waves of EEG in rats with or without aminopterin-treatment. $E E G$ was examined at the age of 6 weeks

\begin{tabular}{|c|c|c|c|c|c|c|c|c|c|c|c|}
\hline \multirow{2}{*}{ Group } & \multirow{2}{*}{$\begin{array}{l}\text { No. } \\
\text { of } \\
\text { rats }\end{array}$} & \multicolumn{10}{|c|}{ Energy \% } \\
\hline & & I & II & III & IV & V & VI & VII & VIII & IX & $\mathrm{X}$ \\
\hline \multirow{4}{*}{ Control } & 19 & 11.1 & 6.9 & 8.2 & 12.8 & 18.4 & 16.4 & 11.1 & 5.7 & 5.7 & 3.6 \\
\hline & 20 & 8.7 & 6.4 & 11.3 & 6.4 & 14.3 & 14.3 & 14.3 & 6.4 & 11.3 & 6.4 \\
\hline & 21 & 6.7 & 5.2 & 7.6 & 7.6 & 18.3 & 19.6 & 14.6 & 8.4 & 6.7 & 5.2 \\
\hline & Average & 8.8 & 6.1 & 9.0 & 8.9 & 17.0 & 16.7 & 13.3 & 6.8 & 7.9 & 5.0 \\
\hline \multirow{4}{*}{$\begin{array}{l}\text { Treated } \\
\text { with } \\
\text { aminopterin }\end{array}$} & 22 & 7.4 & 7.4 & 11.6 & 7.4 & 16.8 & 16.8 & 16.8 & 4.2 & 7.4 & 4.2 \\
\hline & 23 & 13.7 & 12.6 & 11.6 & 8.8 & 12.6 & 9.7 & 10.6 & 7.1 & 7.1 & 6.3 \\
\hline & 24 & 11.9 & 10.2 & 15.9 & 11.9 & 13.8 & 13.8 & 11.9 & 4.5 & 3.5 & 2.5 \\
\hline & Average & 11.0 & 10.0 & 13.0 & 9.3 & 14.4 & 13.4 & 13,1 & 5.2 & 6.0 & 4.3 \\
\hline
\end{tabular}

TABLE 5. Results of frequency analysis of basic waves of EEG in rats with or without aminopterin-treatment. EEG was examined at the age of 7 weeks

\begin{tabular}{|c|c|c|c|c|c|c|c|c|c|c|c|}
\hline \multirow{2}{*}{ Group } & \multirow{2}{*}{$\begin{array}{l}\text { No. } \\
\text { of } \\
\text { rats }\end{array}$} & \multicolumn{10}{|c|}{ Energy \% } \\
\hline & & I & II & III & IV & V & VI & VII & VIII & IX & $\mathrm{X}$ \\
\hline \multirow{4}{*}{ Control } & 25 & 7.1 & 8.2 & 9.5 & 9.5 & 9.5 & 10.9 & 14.0 & 10.9 & 10.9 & 9.5 \\
\hline & 26 & 3.9 & 3.9 & 7.9 & 9.6 & 15.5 & 15.5 & 17.8 & 11.4 & 7.9 & 6.4 \\
\hline & 27 & 4.7 & 4.7 & 7.9 & 10.6 & 13.6 & 24.9 & 15.2 & 7.9 & 5.7 & 4.7 \\
\hline & Average & 5.2 & 5.6 & 8.4 & 9.9 & 12.8 & 16.9 & 15.6 & 10.0 & 8.1 & 6.8 \\
\hline \multirow{4}{*}{$\begin{array}{l}\text { Treated } \\
\text { with } \\
\text { aminopterin }\end{array}$} & 28 & 7.7 & 7.1 & 8.4 & 9.9 & 9.9 & 9.9 & 15.0 & 13.1 & 9.9 & 9.9 \\
\hline & 29 & 6.7 & 7.4 & 10.0 & 12.9 & 12.9 & 12.9 & 10.0 & 10.0 & 10.0 & 7.4 \\
\hline & 30 & 7.8 & 7.8 & 12.7 & 18.7 & 16.6 & 14.6 & 11.0 & 5.2 & 3.2 & 2.3 \\
\hline & Average & 7.4 & 714 & 10.3 & 13.8 & 13.1 & 12.4 & 12.0 & 9.4 & 7.7 & 6.5 \\
\hline
\end{tabular}

Figs. 2-6 were drawn from average values of energy $\%$ at each band in rats with or without the aminopterin treatment at various age groups.

There was no difference in analytic patterns of EEG between control rats and rats treated with aminopterin when EEG was examined at the age of 3 and 4 weeks (cf. Figs. 2 and 3). 


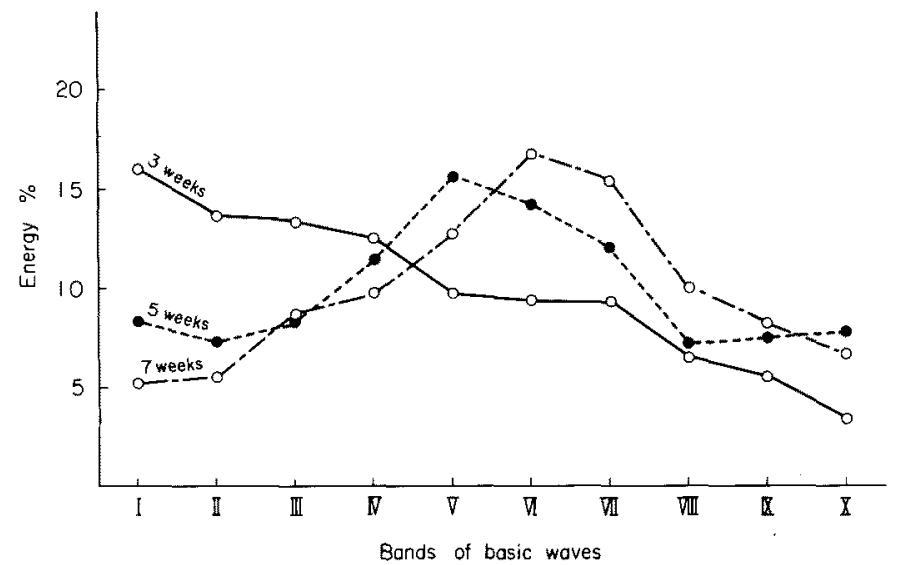

Fig. 1 Distribution of energy \% at each band of basic waves in control rats at various ages.

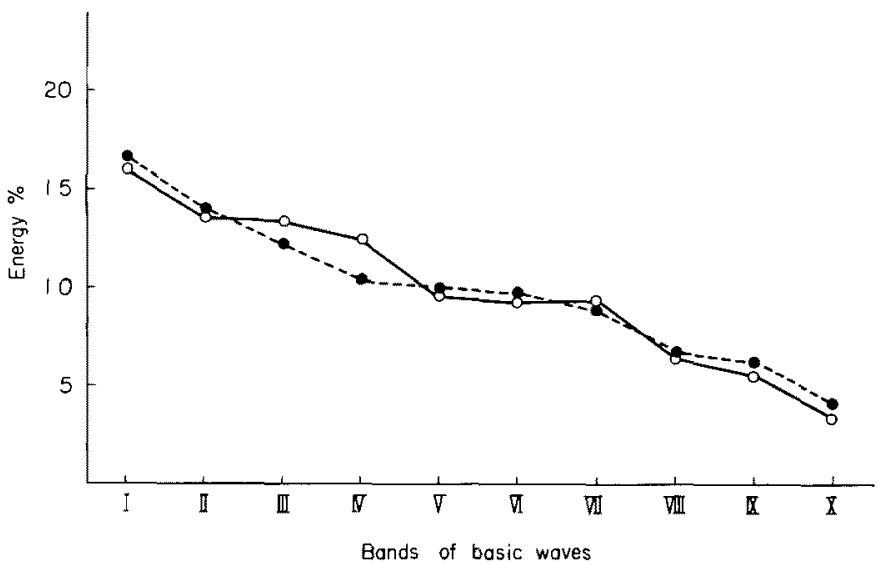

Fig. 2. Distribution of energy \% at each band of basic waves in control (o- - o) and aminopterin-treated rats $(\cdot \ldots \cdot)$. EEG was taken at the age of 3 weeks.

At the age of 5,6 and 7 weeks, a definite difference in analytic patterns of EEG was found between control rats and rats treated with aminopterin, that is, an increase in energy \% at bands I-III associated with a decrease in energy \% at bands VI-VIII in rats treated with aminopterin.

On taking into consideration the maturation pattern of EEG of control rats shown in Fig. 1, it may be conceivable that folic acid deficiency in early infancy brings about a delay in maturation of the brain function of rats when examined at the age of 5,6 and 7 weeks by using a frequency analyzer specially prepared.

In 1966 Adams $^{1}$ has reported that, in the rat cerebral cortex net DNA synthesis ceased comparatively early, about 18 days of life.

In 1966 Winick and Noble ${ }^{2}$ investigated cellular response in various organs of rats with malnutrition during various ages and coneluded that cell division in the 


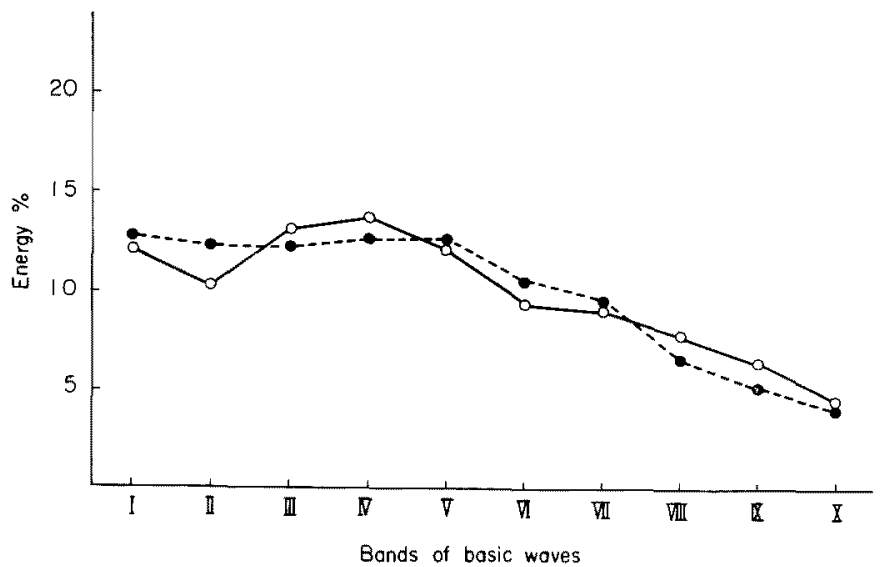

Fig. 3. Distribution of energy $\%$ at each band of basic waves in control ( 0 - o) and aminopterin-treated rats $(\bullet \cdots \cdot \cdot)$. EEG was examined at the age of 4 weeks.

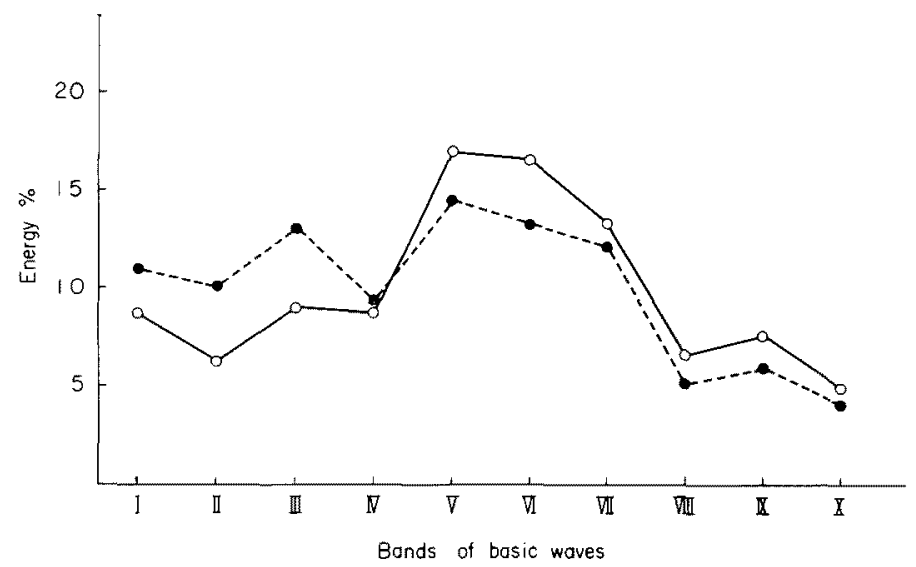

Fig. 4. Distribution of energy \% at each band of basic waves in control $(0-0)$ and aminopterin-treated rats $(\cdot \cdots \cdots \bullet)$. EEG was examined at the age of 5 weeks.

rat brain might be retarded by malnutrition during the period of active DNA synthesis, and that growth under these conditions produced a brain with a reduced number of cells.

In the present study, aminopterin was given to both dams and offsprings during a period of active DNA synthesis of the brain of offsprings. This medication may produce, to some extent, an impairment in DNA and RNA synthesis in the brain of offsprings, with a result of delay in maturation of the brain function. 


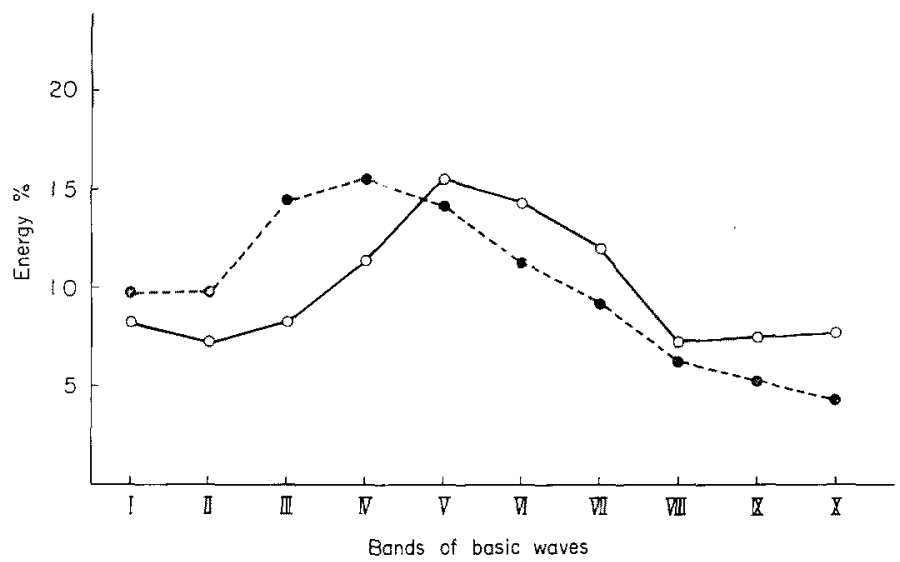

Fig. 5. Distribution of energy \% at each band of basic waves in control $(0-0)$ and aminopterin-treated rats $(\cdot \cdots \cdots \cdot$. EEG was examined at the age of 6 weeks.

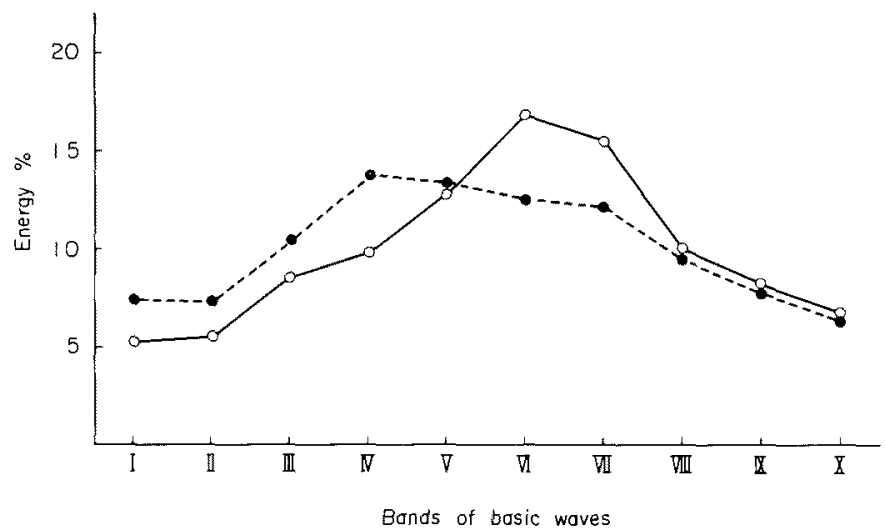

Fig, 6. Distribution of energy $\%$ of basic waves in control $(\circ-0)$ and aminopterin-treated rats $(\cdots \cdots \cdots)$. EEG was examined at the age of 7 weeks.

\section{References}

1) Adams, D.H. The relationship between cellular nucleic acids in the developing rat cerebral cortex. Biochem. J., 1966, 98, 636-640.

2) Winick, M. \& Noble, A. Cellular response in rats during malnutrition at various ages. J. Nutr., 1966, 89, 300-306. 